\title{
Revisiting Sovereign Ratings, Capital Flows and Financial Contagion in Emerging Markets
}

\author{
Noha Emara ${ }^{1,2}$ and Ayah El Said ${ }^{3}$ \\ Received: 12/11/2015 Revised: 16/12/2015 Accepted: 26/12/2015
}

\begin{abstract}
This study revisits sovereign credit ratings, contagion and capital flows to Emerging Markets (EMs), and clarify the relationship between them. Specifically, this study analyzes how the changes in sovereign rating influence different types of capital flows to EMs and whether the changes in the different kinds of capital flows in one country be explained by a sovereign ratings' change in another country. Using Arellano-Bover/Blundell-Bond Dynamic Panel System GMM for 23 EMs over the period 1990-2012 the results of the study suggest that sovereign ratings is a crucial factor for EMs' access to international capital markets and that capital flows is a major source of financing for Ems. In addition, the results show that financial contagion may continue to be a threat to capital flowing into EMs and that financial crisis increases the impact of sovereign rating on foreign direct investment but is not the case with portfolio investment.
\end{abstract}

Keywords: Sovereign Rating; Capital Flows; System GMM; Foreign Direct Investment; Portfolio Investment

JEL Codes: O16, O43, N20

\footnotetext{
${ }^{1}$ Department of Economics, Rutgers University, Camden NJ, USA.

${ }^{2}$ Corresponding Author: email: nemara@camden.rutgers.edu

${ }^{3}$ Department of Economics, City University London, UK
} 


\section{Introduction}

In the early 1990s, emerging markets (EMs) witnessed an unprecedented surge in private capital flows in both portfolio and foreign direct investment (FDI). Portfolio flows jumped from an average of about US\$6 billion annually in the period 1982-88, to almost US\$34 billion in 1992, with Latin American countries receiving the bulk of this increase (World Bank 1993). Additionally, the world's FDI soared from US\$192 billion in 1988 to US\$610 billion in 1998, with EMs receiving almost one quarter of total FDI (World Bank 2000).

This phenomenon has been attributed to several factors including low investment prospects in developed countries, and low U.S. interest rates, which caused investments in EMs to be more attractive, the studies of Fernandez-Arias (1996) and Montiel and Reinhart (1999) are a good reference in this respect. However, a different line of thought emphasizes the role played by credit rating agencies (CRAs) in EM lending. CRAs provide information about a country's creditworthiness in terms of its economic stance, and its probability of default. The information collected on a sovereign government's willingness and ability to pay its debt in full, and in a timely manner, is known as a sovereign rating. Several studies identified the most important factors that determine sovereign ratings [See for example Cantor and Packer (1996) and Juttner and McCarthy (1998)].

Ratings are most important for economies whose access to international capital markets varies greatly, as in the case for EMs. Due to information asymmetries prevalent in EMs, international investors were previously deterred from investing in unrated countries. However, realizing that foreign investment was likely to increase once EMs were rated, the number of rated countries increased from 12 in 1980 to around 100 in 2002 (Carlson and Hale 2005). Ratings have thus increased sovereign governments' access to international capital markets and enhanced their ability to raise funds at lower cost.

CRAs came under severe scrutiny, however, following repeated defaults in the 1990s and the occurrence of crises such as the Tequila crisis (1994/95), the Asian flu (1997/1998) and the Russian virus in 1998. The instability caused by these crises resulted in enormous capital outflows and to "sudden stops" in severe circumstances (Calvo 1998). The failure of CRAs to predict these crises, and their downgrading of sovereign ratings after the fact, led to the belief that they may have actually aggravated the crises.

Given the nature of sovereign ratings as a stimulant to EMs' access to international capital markets, and the fact that they influence international investment decisions, capital flows have a tendency to respond to rating changes. There is also a possibility that this response is contagious and can spread across countries in crisis periods. This spread might happen even though ratings changes in other countries may have not occurred.

However, only a few studies have attempted to empirically analyze the relationship between sovereign ratings, capital flows, and contagion. Also, only a handful of studies attempted to investigate whether changes in sovereign ratings affected the types of capital flows differently. Such differences are probable given that capital flows vary in nature. Hence, breaking up the different types of capital flows permits the investigation of how capital flows respond to changes in sovereign ratings in different ways. Chuhan, 
Claessens, and Mamingi (1993), as well as Taylor and Sarnor (1997) were among the pioneering studies in this area. Moreover, previous research did not investigate whether changes in ratings affect capital flows uniformly across countries, as compared to their effect in the ground zero country ${ }^{4}$.

Thus, the purpose of this study is to revisit sovereign credit ratings, contagion and capital flows to EMs, and clarify the relationship between them. Specifically, this study will attempt to answer the following questions: how do rating changes influence different types of capital flows to EMs? Can changes in the different kinds of capital flows in one country be explained by a sovereign ratings' change in another country?

This study is organized as follows: Section 2 discusses the literature review. Section 3 presents the data. Section 4 presents the model specification and methodology. Section 5 presents the empirical results and Section 6 concludes this study. Finally, the references appear at this study's conclusion.

\section{Literature Review}

It should be noted that there is a vast amount of literature on sovereign ratings, capital flows, and contagion. However, the literature that combines those three strands is not as vast. The literature on the importance of sovereign ratings and their role in financial markets appeared after the 1994 Mexican crisis. Cantor and Packer (1996) found that CRAs supply information about speculative grade ${ }^{5}$ sovereigns more than that present in public information. Reinhart (2002) and Kraussl (2003) asserted that sovereign credit ratings are principally central for EMs. This is because the accessibility of EMs to international capital markets is unstable, and varies strongly over time.

The literature on the determinants of capital flows divides the determinants into push (external) factors, and pull (country specific) factors. Fernandez-Arias and Montiel (1995) found that international interest rates were a major determinant of the size of capital inflows to developing countries. Fernandez-Arias (1996) concluded that the rate of return in developed countries is also an important push factor. Calvo and Reinhart (1996) and Chuhan et al. (1998), found that the GDP growth rate of the developed countries is also a major push factor. Regarding the pull factors, Fernandez-Arias and Montiel (1995) constructed a creditworthiness index and inferred that creditworthiness was a major determinant of the direction of capital flows ${ }^{6}$.

As for contagion, there is a comprehensive theoretical and empirical literature on the international spreading of shocks. Eichengreen, Rose, and Wyplosz (1997) examined quarterly macro and political data on 20 OECD countries, and found that trade links are the principal transmission channel through which financial crises spread across countries. Glick and Rose (1998) used panel data of 161 countries and reached the same conclusion.

We now move on to review the literature that most commonly combines sovereign ratings, capital flows and financial contagion. The first study was by Chuhan, Claessens,

\footnotetext{
4 The ground zero country is the country that was first downgraded.

5 Defined as "non-investment-grade" in Cantor and Packer (1996): Speculative grade sovereigns are countries that have a higher risk of default. A guaranteed investment, or at least an investment with a high probability of return, is better allocated in country with ratings in the investment grade band.

${ }^{6}$ However, their credit worthiness index did not include sovereign ratings as a proxy for creditworthiness.
} 
and Mamingi (1993) which used panel data for the period 1988-1992 on U.S. capital flows to nine Latin American countries and nine Asian countries. They found that bond flows were quicker to respond to a country's credit rating than equity flows.

Calvo and Reinhart (1996) studied proof of contagion in Asia and Latin America prior to and post the December 1994 Mexican crisis. They also studied proof of "large neighbor effects" in capital flows to and from Latin America from 1970-1993. Several results were found: primarily, the degree of comovement across equity and bond returns in Latin America increased with the outbreak of the Mexican crisis.

As an extension to Chuhan, Claessens, and Mamingi (1993), Taylor and Sarno (1997) analyzed the determinants of U.S. capital flows to nine Latin American and nine Asian countries from 1988- 1992. They found that long term equity and bond flows are evenly sensitive to the push and pull factors employed, and that a country's domestic credit rating assisted in explaining the pattern of U.S. portfolio flows to the countries under study.

Kaminsky and Schmukler (2002) concluded that in addition to significantly affecting bond and stock markets, changes in ratings resulted in contagion, or spillover, effects. Kraussl (2003) found that changes in sovereign ratings of the ground-zero country significantly affected financial markets of other emerging markets.

Albuquerque (2003), on the other hand, regressed the share of FDI in gross capital flows on the ratings assigned. He found an inverse relationship between them, and concluded that changes in FDI flows maybe explained by the change in ratings.

\section{Data}

The data set is constructed as a panel of country observations from the World Development Indicators of the World Bank's database of 2015. The data set includes 23 EMs over the period 1990-2012. The list of countries included in the sample is reported in Table 1.

\section{Table 1: List of EMs included in the Sample}

\begin{tabular}{|l|l|r|l|}
\hline 1 & Argentina & 13 & Malaysia \\
\hline 2 & Brazil & 14 & Mexico \\
\hline 3 & Chile & 15 & Peru \\
\hline 4 & China & 16 & Philippines \\
\hline 5 & Columbia & 17 & Poland \\
\hline 6 & Czech Republic & 18 & Russia \\
\hline 7 & Egypt & 19 & Singapore \\
\hline 8 & Hong Kong & 20 & South Africa \\
\hline 9 & Hungary & 21 & Thailand \\
\hline 10 & India & 22 & Turkey \\
\hline 11 & Indonesia & 23 & Venezuela \\
\hline 12 & Korea, Rep. & & \\
\hline
\end{tabular}

The dependent variable consists of the two different types of capital flows: FDI (as a share of GDP) and foreign portfolio investment (as a share of GDP). The set of independent variables consist of the current account balance as a share of GDP, the real interest rate, inflation rate, real GDP growth rate, Standard and Poor's sovereign ratings, 
the weighted average of the G- $7^{7}$ real GDP growth rate, and the weighted average of the G-7 real interest rate.

The data on the sovereign debt rating is collected from the Moody's sovereign debt ratings ${ }^{8}$ which indicate the capacity and willingness of a government to repay back its obligations in full and on time. The Moody's rating, that relates to foreign currency, focus on measuring the expected credit loss, which depends on the probability of default and the expected recovery rate after the default has occurred ${ }^{9}$. More specifically, the sovereign debt rating for a given government is defined as the risk facing an investor who holds debt securities issued by that government which in turn reflects its credit worthiness.

\section{Model Specification and Methodology}

The methodology can be divided into two parts. First, we shall examine the impact of a ratings change on different types of capital flows, and then investigate whether or not this impact displays a contagion effect.

Thus, for examining the impact of a ratings change on different types of capital flows, we form the subsequent dynamic panel regression model:

$$
\begin{gathered}
K I_{i, t}=\alpha+\rho K I_{i, t-1}+\beta X_{i, t-1}+\delta Z_{i, t-1}+\lambda R_{i, t-1}+\varepsilon_{i t} \\
i=1,2, \ldots, N, \quad t=1990, \ldots, T
\end{gathered}
$$

where $K I_{i t}$ denotes the ratio of capital flows, of a certain type, to GDP, of country $i$, at time $t$. This ratio is taken rather than the absolute figure of capital flows to control for country size. $K I_{i t-1}$ is the lagged endogenous variable, while $X_{i t-1}$ and $Z_{i t-1}$ are vectors of pull and push factors, respectively. $R_{i t-1}$ represents the sovereign rating change of country $i$ at time $t-1$. Finally, $\varepsilon_{i t}$ is the error term.

To account for causality, one-period lagged values of the pull factors, and the sovereign ratings, will be included so that they become predetermined within the model. ${ }^{10}$ Similar to Gande and Parsley (2003) a ratings change will comprise any amendments in sovereign ratings, and credit outlooks. ${ }^{11}$

\footnotetext{
${ }^{7}$ France, Canada, Italy, Germany, U.S., U.K. and Japan.

${ }^{8}$ Aaa, Aa1, Aa2, Aa3, Aa, A1, A2, A3, A, ,Baa1, Baa2, Baa3,Ba1, Ba2, Ba3, B1, B2, B3,Caa1, Caa2, Caa3, $\mathrm{Ca}, \mathrm{C}$. For detailed definition on each rating classification check Rowland (2005).

${ }^{9} L_{e}=\rho(d) .\left(1-r_{e}\right), L_{e}=\rho(d)\left(1-r_{e}\right)$ where $L_{e}$ is the expected loss, $\rho(d)$ is the probability of default, and $r_{e}$ is the expected recovery rate as noted in Bhatia (2002).

${ }^{10}$ Causality problems may arise, as pointed out by Kang et. al. (2003) because some pull factors might be influenced by capital flows.

${ }^{11}$ Credit outlooks are included since, usually, sovereign states are put on what is known as a "credit watch" that can be positive or negative several months prior to an actual upgrade or downgrade which can have an effect on the flow of capital. It should be noted that it is not at all necessary that a country placed on a credit watch to have its rating adjusted.
} 
Table 2: Definitions of Variables

\begin{tabular}{|c|c|c|c|}
\hline Variable Name & Definition & $\begin{array}{c}\text { Unit of } \\
\text { Measurement }\end{array}$ & Data Source \\
\hline $\begin{array}{l}\text { Foreign direct } \\
\text { investment, net } \\
\text { inflows }(\% \text { of } \\
\text { GDP })\end{array}$ & $\begin{array}{l}\text { It is the sum of equity capital, reinvestment of } \\
\text { earnings, other long-term capital, and short-term } \\
\text { capital as shown in the balance of payments. } \\
\text { This series shows net inflows (new investment } \\
\text { inflows less disinvestment) in the reporting } \\
\text { economy from foreign investors, and is divided } \\
\text { by GDP. }\end{array}$ & Percent & $\begin{array}{l}\text { World } \\
\text { Development } \\
\text { Indicators } \\
(2015) .\end{array}$ \\
\hline $\begin{array}{l}\text { Portfolio } \\
\text { investment, } \\
\text { bonds (\% of } \\
\text { current US\$) }\end{array}$ & $\begin{array}{l}\text { Bonds are securities issued with a fixed rate of } \\
\text { interest for a period of more than one year. They } \\
\text { include net flows through cross-border public } \\
\text { and publicly guaranteed and private } \\
\text { nonguaranteed bond issues. Data are in current } \\
\text { U.S. dollars }\end{array}$ & Percent & $\begin{array}{l}\text { World } \\
\text { Development } \\
\text { Indicators } \\
(2015) .\end{array}$ \\
\hline $\begin{array}{l}\text { Sovereign debt } \\
\text { rating }\end{array}$ & Ratings assigned by Standard \& Poors (S\&P) & $\begin{array}{l}\mathrm{Aaa}=23, \\
\mathrm{Aa} 1=22 \ldots . \mathrm{C}=1\end{array}$ & $\begin{array}{l}\text { S\&P } 500 \text { Index } \\
(2013)\end{array}$ \\
\hline Inflation & The percentage change in consumer price index & Percent & $\begin{array}{l}\text { World } \\
\text { Development } \\
\text { Indicators } \\
(2015) .\end{array}$ \\
\hline $\begin{array}{l}\text { Real Interest } \\
\text { Rate }\end{array}$ & $\begin{array}{l}\text { Real interest rate is the lending interest rate } \\
\text { adjusted for inflation as measured by the GDP } \\
\text { deflator. }\end{array}$ & Percent & $\begin{array}{l}\text { World } \\
\text { Development } \\
\text { Indicators } \\
(2015) \text {. }\end{array}$ \\
\hline $\begin{array}{l}\text { Current } \\
\text { Account } \\
\text { Balance }(\% \text { of } \\
\text { GDP })\end{array}$ & $\begin{array}{l}\text { Current account balance is the sum of net } \\
\text { exports of goods and services, net primary } \\
\text { income, and net secondary income. }\end{array}$ & Percent & $\begin{array}{l}\text { World } \\
\text { Development } \\
\text { Indicators } \\
(2015) .\end{array}$ \\
\hline $\begin{array}{l}\text { Growth of real } \\
\text { per capita GDP }\end{array}$ & $\begin{array}{l}\text { Change in the log of real GDP per capita } \\
\text { (constant } 2000 \text { US } \$ \text { ). (Authors computation) }\end{array}$ & Percent & $\begin{array}{l}\text { World } \\
\text { Development } \\
\text { Indicators } \\
(2015) .\end{array}$ \\
\hline $\begin{array}{l}\text { G-7 real GDP } \\
\text { growth rate }\end{array}$ & $\begin{array}{l}\text { Weighted average by GDP per capita of real } \\
\text { GDP per capita for the G-7 countries. (Authors } \\
\text { computation) }\end{array}$ & Percent & $\begin{array}{l}\text { World } \\
\text { Development } \\
\text { Indicators } \\
(2015) \text {. }\end{array}$ \\
\hline $\begin{array}{l}\text { G-7 real interest } \\
\text { rate }\end{array}$ & $\begin{array}{l}\text { Weighted average by GDP per capita of real } \\
\text { GDP per capita for the G-7 countries. (Authors } \\
\text { computation) }\end{array}$ & Percent & $\begin{array}{l}\text { World } \\
\text { Development } \\
\text { Indicators } \\
(2015) .\end{array}$ \\
\hline
\end{tabular}

For the endogenous variables, $K I$, we shall disaggregate the capital flows, and study the determinants of the main constituents of the financial account: FDI (as a share of GDP), foreign portfolio investment, (as a share of GDP), and short term flows (as a share of GDP).

As for the exogenous variables, we shall divide them into two groups: push factors and pull factors. The push factors encompass the weighted average of the G-7 real GDP growth rate, and the weighted average of the G-7 real interest rate. The vector of pull factors will include the current account balance as a share of GDP, the real interest rate, 
inflation rate, real GDP growth rate, the degree of openness (calculated as the ratio of exports and imports to GDP), and Standard and Poor's sovereign ratings.

Sovereign rating changes made by Standard \& Poor's (S\&P) are the only ratings employed in this study. Li (2004) and Gande and Parsley (2004b) were among the studies that maintained S\&P as the principal rating agency, and is a reflection of the ratings assigned by the other agencies in the market. The time period covered will be from 1990 until 2012. The hypothesis that will be tested here is that sovereign ratings significantly affect the different types of capital flows. That is, a ratings downgrade/upgrade for country $i$ will affect different types of capital flow in country $i$.

Equation (1) will be estimated using the General Method of Moments estimator (GMM). Ordinary Least Squares (OLS) and the Least Square Dummy Variable (LSDV) estimators, if used, will result in biased estimators, and in inconsistent estimators (Hsiao (2003)) respectively. More specifically, the presence of a lagged endogenous variable suggests that correlation will exist between the latter and the error term, resulting in biased estimators. The GMM, however, will evade correlation problems (Yaffee (2003)), and will consistently estimate the dynamic panel data model (Kitazawa (2003)).

Following Caselli, Equivel and Lefort (1996), Holtz-Eakin, Newey and Rosen (1988) and Arellano and Bond (1991), the capital flows model is estimated using dynamic panel System GMM. Equation (1) provides the general form of the empirical model.

The System GMM proposed by Arellano and Bover (1995), Blundell and Bond (1998), and Blundell, Bond, and Windmeijer(2000) overcomes the bias problems of the difference GMM estimator. It works by basically stacking together Equation (1) with Equation (2) below:

$$
\begin{aligned}
\left(K I_{i, t}-K I_{i, t-1}\right)= & \alpha+\rho\left(K I_{i, t-1}-K I_{i, t-2}\right)+\beta\left(X_{i, t-1}-X_{i, t-2}\right) \\
& +\gamma\left(R_{i, t-1}-R_{i, t-2}\right)+\left(\varepsilon_{i, t}-\varepsilon_{i, t-1}\right)
\end{aligned}
$$

The main reason for differencing Equation (1) is to eliminate the country specific or unobserved effects following Arellano and Bond (1991). In addition to the assumptions of the Difference GMM ${ }^{12}$, the System GMM assumes that the first difference of the dependent variable and the explanatory variables are uncorrelated with the country specific effects which provides the following two extra moments conditions about the correlation between the dependent variable and the error term and the set of the independent variables and the error term,

$$
\begin{aligned}
& E\left[\Delta K_{i, t} \varepsilon_{i t}\right]=0 \quad \text { for } t=2, \ldots, T \\
& E\left[\Delta M_{i, t} \varepsilon_{i t}\right]=0 \quad \text { for } t=2, \ldots, T
\end{aligned}
$$

where $M_{i, t}$ is the set of all the explanatory variables of Equation (1) except the push factors, $Z_{i}$. In order to satisfy these additional moments conditions, the correct set of instruments was chosen by regressing the dependent variable and each of the explanatory variables in levels, each variable in a turn, on all the possible lags of the dependent

${ }^{12}$ More details on Difference GMM are available in Traub (2006). 
variable and the explanatory variables in first difference starting from the second lag in addition to time dummies. The instruments were chosen in such a way that a unique set of instrument for $K_{i, t-1}$ and $M_{i, t-1}$ can be found. This set of instruments usually consists of the second lag of $y_{i, t}$ and $M_{i, t}$ plus any other extra instruments that appear to be also significant.

For the set of instruments to be valid, it has to be both relevant and exogenous to the error term. The relevance test checks and makes sure that the first stage F-statistic equals or exceeds 10 or in other words that the bias of the Two Stage Least Squares is at most $10 \%$ of the bias of the Ordinary Least Squares methodology ${ }^{13}$. The exogeneity test or "Over Identification Test", or as know by Sargan test (Sargan 1988), tests that the moments conditions of Equation (3) above are satisfied.

As for testing for contagion effects among capital flows, we follow Hernandez, Mellado, and Valdes (2001), and focus on the likelihood of the presence of "pure" contagion. This entails a considerable co-movement in capital flows when changes in the determinants of capital flows are controlled for.

By employing a dynamic panel regression model, the response of capital flows of EM country $i$ to changes in the sovereign rating of EM country $j$ will be measured. The following dynamic panel regression model is formed;

$$
K I_{i, t}=\alpha+\rho K I_{i, t-1}+\beta X_{i, t-1}+\delta Z_{i, t}+\sigma \sum_{j=1}^{N} R_{j t}+\varepsilon_{i t}
$$

The dependent variables are the same as before, as well as the vectors of push and pull factors. However, the explanatory variables in this equation contain $\sum R_{j t}$ which represents the sum of the changes in ratings elsewhere $(i \neq j)^{14} . \sum R_{j t}$ is a weighted average of the BRICS countries' rating controlled for country size ${ }^{15}$.

Equation (3) will also be estimated using the GMM, and the hypothesis that will be tested here is that sovereign ratings changes in other countries $(j \neq i)$ significantly affect the different types of capital flows in country $i$. That is, a rating downgrade (upgrade) in country $j$ will cause the different types of capital to flow out of (into) country $i$.

\section{Estimation Results}

To avoid the endogeneity problem that might arise from causality -from capital inflows to one or more of the determinants and vice versa- leading to a possible correlation between the set of regressors and the residual term of the regression, the Arellano-Bond estimation methodology is used. Also the presence of lagged capital flows variable suggest that an autocorrelation would be present between the latter and the error term. Furthermore, the time invariant country characteristics may be correlated with the set of regressors.

\footnotetext{
13 The book of Stock, J., Watson, M., (2006) provides good explanation on the TSLS.

${ }^{14}$ Note that country j may be referred to as the ground zero country in this case.

15 This occurs by multiplying the value of country j's regional discrete variable by its GDP, relative to the total GDP of the countries in the region.
} 
The model is estimated under nine specifications of the independent variables. In each specification, the dependent variable is a type of capital flows; foreign direct investment as a percent of GDP or portfolio investment as a percent of GDP. The focus is on the partial correlations between the type of capital flows and the sovereign debt rating.

To estimate the model using Dynamic Panel System GMM, first the correct set of instruments must pass the instrument relevance test as well as the instrument exogeneity test. For the former test the F-statistic for the regressions in which each regressor is regressed on the whole set of instruments must exceed ten.

For the instrument exogeneity test, or over-identification test, the hypothesis that the instruments are exogenous to the error term is tested. The hypothesis is rejected if the calculated $\mathrm{J}$-statistic ${ }^{16}$ exceeds a chi-squared with $\mathrm{m}$ minus $\mathrm{k}$ restrictions at a chosen significant level, where $\mathrm{m}$ and $\mathrm{k}$ refer to the number of instruments and the number of endogenous regressors respectively. In addition, the Sargan p-value is calculated.

Table 3 shows the results of estimating nine specifications for the FDI regression. Column 1 shows the results of the FDI regression with only an AR(1) term where the sign and significance of the lagged FDI is as expected. When the lagged GDP growth rate is added to the regression (Column 2 in Table 3), the coefficient of the lagged rating remains significant. The coefficient of GDP growth is also significant and the magnitude of this coefficient indicates that a one percent increase in GDP growth rate corresponds to about 0.499 percent increase in foreign direct investment.

Next, adding lagged sovereign debt rating to the regression (Column 3 in Table 3), the coefficient of the lagged FDI remains significant. The coefficient of lagged rating shows a statistically significant positive coefficient implying that one classification increase in the sovereign rating corresponds to about 0.142 percent increase in FDI.

When lagged inflation is added to the regression (Column 4 in Table 3), the coefficients of the lagged FDI, lagged GDP growth, and lagged rating do not change in terms of the signs and statistical significance. The coefficient of the lagged inflation rate, however, shows an unexpectedly statistical insignificant impact on FDI. Similar results are obtained when adding the lagged interest rate (Column 5 in Table 3) and lagged current account as a percent of GDP (Column 6 in Table 3).

${ }^{16}$ Equal to the number of instruments multiplied by the second stage F-statistic. 


\section{Table 3: Foreign Direct Investment and Sovereign Rating}

Dependent variable: Foreign Direct Investment (\% of GDP)

Estimation Method: Arellano-Bover/Blundell-Bond Dynamic Panel System GMM.

\begin{tabular}{|c|c|c|c|c|c|c|c|c|c|}
\hline & [1] & {$[2]$} & [3] & [4] & [5] & [6] & [7] & [8] & [9] \\
\hline $\mathrm{FDI}_{i t-1}$ & $\begin{array}{c}0.707 * * \\
* \\
(0.032)\end{array}$ & $\begin{array}{c}0.695 * * * \\
(0.027)\end{array}$ & $\begin{array}{c}0.606^{* * *} \\
(0.90)\end{array}$ & $\begin{array}{c}0.602 * * * \\
(0.034)\end{array}$ & $\begin{array}{c}0.603 * * * \\
(0.035)\end{array}$ & $\begin{array}{l}0.601 * * * \\
(0.045)\end{array}$ & $\begin{array}{c}0.625^{* * *} * \\
(0.057)\end{array}$ & $\begin{array}{c}0.627 * * * \\
(0.058)\end{array}$ & $\begin{array}{c}0.627 * * * \\
(0.042)\end{array}$ \\
\hline GDP Growth $_{i t-1}$ & & $\begin{array}{l}0.499 * * * \\
(0.218)\end{array}$ & $\begin{array}{c}0.446 * * \\
(0.199)\end{array}$ & $\begin{array}{l}0.540 * * \\
(0.236)\end{array}$ & $\begin{array}{l}0.566 * * \\
(0.232)\end{array}$ & $\begin{array}{l}0.547 * * * \\
(0.228)\end{array}$ & $\begin{array}{l}0.329 * \\
(0.181)\end{array}$ & $\begin{array}{c}0.293 * * \\
(0.176)\end{array}$ & $\begin{array}{l}0.249 * \\
(0.159)\end{array}$ \\
\hline Rating it-1 & & & $\begin{array}{l}0.142 * * * \\
(0.053)\end{array}$ & $\begin{array}{l}0.145^{* *} \\
(0.051)\end{array}$ & $\begin{array}{c}0.138 * * * \\
(0.047)\end{array}$ & $\begin{array}{l}0.133 * * * \\
(0.033)\end{array}$ & $\begin{array}{l}0.104 * * \\
(0.040)\end{array}$ & $\begin{array}{c}0.141^{* * * *} \\
(0.045)\end{array}$ & $\begin{array}{l}0.144 * * \\
(0.063)\end{array}$ \\
\hline Inflation it-1 & & & & $\begin{array}{l}-0.002 \\
(0.004)\end{array}$ & $\begin{array}{l}-0.012 \\
(0.010)\end{array}$ & $\begin{array}{l}-0.013 \\
(0.009)\end{array}$ & $\begin{array}{l}-0.016 \\
(0.013)\end{array}$ & $\begin{array}{l}-0.004 \\
(0.009)\end{array}$ & \\
\hline Real Interest Rate $_{i t-1}$ & & & & & $\begin{array}{c}0.021 \\
(0.017)\end{array}$ & $\begin{array}{c}0.022 \\
(0.022)\end{array}$ & $\begin{array}{l}-0.005 \\
(0.035)\end{array}$ & $\begin{array}{l}-0.001 \\
(0.039)\end{array}$ & \\
\hline Current Account ${ }_{i t-I}$ & & & & & & $\begin{array}{c}0.030 \\
(0.087)\end{array}$ & $\begin{array}{c}0.047 \\
(0.078)\end{array}$ & $\begin{array}{c}0.031 \\
(0.076)\end{array}$ & \\
\hline G-7 Growth ${ }_{i t}$ & & & & & & & $\begin{array}{l}0.973 * \\
(0.592)\end{array}$ & $\begin{array}{l}1.227^{*} \\
(0.657)\end{array}$ & $\begin{array}{c}1.049 * * \\
(0.504)\end{array}$ \\
\hline G-7 Real Interest ${ }_{i t}$ & & & & & & & & $\begin{array}{c}-0.209 * * \\
(0.096)\end{array}$ & $\begin{array}{c}-0.177 * * \\
(0.087)\end{array}$ \\
\hline $\begin{array}{l}\text { Countries/Observati } \\
\text { ons }\end{array}$ & $23 / 493$ & $23 / 487$ & $23 / 435$ & $23 / 397$ & $22 / 367$ & $22 / 366$ & $22 / 366$ & $22 / 366$ & $23 / 435$ \\
\hline Arellano-Bond Test & & & & & & & & & \\
\hline Order 1 & $\begin{array}{c}- \\
2.042 * *\end{array}$ & $\begin{array}{c}-2.157 * * \\
{[0.031]}\end{array}$ & $\begin{array}{c}-2.269 * * \\
{[0.023]}\end{array}$ & $\begin{array}{c}-2.161 * * \\
{[0.030]}\end{array}$ & $\begin{array}{c}-2.169 * * \\
{[0.030]}\end{array}$ & $\begin{array}{c}-2.190 * * \\
{[0.028]}\end{array}$ & $\begin{array}{c}-2.192 * * \\
{[0.028]}\end{array}$ & $\begin{array}{c}-2.213 * * \\
{[0.027]}\end{array}$ & $\begin{array}{c}-2.304 * * \\
{[0.021]}\end{array}$ \\
\hline Order 2 & $\begin{array}{c}{[0.041]} \\
-1.265 \\
{[0.206]}\end{array}$ & $\begin{array}{l}-1.244 \\
{[0.214]}\end{array}$ & $\begin{array}{l}-1.222 \\
{[0.222]}\end{array}$ & $\begin{array}{l}-1.226 \\
{[0.220]}\end{array}$ & $\begin{array}{l}-1.212 \\
{[0.225]}\end{array}$ & $\begin{array}{l}-1.214 \\
{[0.225]}\end{array}$ & $\begin{array}{l}-1.223 \\
{[0.221]}\end{array}$ & $\begin{array}{l}-1.222 \\
{[0.222]}\end{array}$ & $\begin{array}{l}-1.223 \\
{[0.221]}\end{array}$ \\
\hline $\begin{array}{l}\text { J-Statistic / Sargan } \\
\text { P-value }\end{array}$ & $\begin{array}{c}4.31 \\
{[0.97]}\end{array}$ & $\begin{array}{l}15.35 \\
{[0.34]}\end{array}$ & $\begin{array}{l}14.55 \\
{[0.41]}\end{array}$ & $\begin{array}{l}15.40 \\
{[0.42]}\end{array}$ & $\begin{array}{l}12.97 \\
{[0.67]}\end{array}$ & $\begin{array}{l}10.39 \\
{[0.92]}\end{array}$ & $\begin{array}{c}10.48 \\
{[0.92]}\end{array}$ & $\begin{array}{c}9.58 \\
{[0.94]}\end{array}$ & $\begin{array}{c}9.58 \\
{[0.94]}\end{array}$ \\
\hline
\end{tabular}

Notes: $* * *, * *$ and $*$ denotes statistical significance at the $1 \%, 5 \%$ and $10 \%$ levels respectively

Numbers in round parentheses (.) are the robust standard errors, and numbers in square parentheses [.] are the Arellano-Bond Autocorrelation Test P-values 
Next, adding the weighted average of the G-7 real GDP growth rate to the regression (Column 7 in Table 3), the coefficient imply a one percent increase in the G-7 weighted average GDP growth leads to 0.973 percent increase in FDI with all the previous results do not change in terms of sign and statistical significance.

Furthermore, adding the second push factor to the regression (Column 8 in Table 3), the results suggest that the G-7 real interest rate has an expected negative influence on FDI in EMs, where a one percent increase in the real interest rate results in 0.209 drop in FDI in EMs.

In the last specification (Column 9 in Table 3) the three insignificant coefficients are dropped and the model is re-estimated where the coefficients of lagged FDI, real GDP growth, sovereign rating, G-7 real growth rate, and G-7 real interest rate are statistically significant with expected signs.

The Arellano-Bond test for autocorrelation (null hypothesis no autocorrelation) is applied to the differenced residuals. The test in first order is usually expected to reject the null. The test in second order is in levels and that is why more important in detecting autocorrelation. As the results of all specifications in Table 3 suggest no autocorrelation in levels between residuals. Finally, the results of Sargan test (null hypothesis instruments as a group are exogenous) suggest that the set of instruments used in all regressions are valid.

Table 4 shows the results of estimating nine specifications for the portfolio investment regression. Column 1 in Table 4 shows the results of the portfolio investment regression with only an $\mathrm{AR}(1)$ term where the sign and significance of the lagged portfolio investment are as expected. When the lagged GDP growth rate is added to the regression (Column 2 in Table 4), the coefficient of the lagged rating remains significant. The coefficient of GDP growth is also significant and the magnitude of this coefficient indicates that a one percent increase in GDP growth rate corresponds to about 0.125 percent increase in portfolio investment.

Next, adding lagged sovereign debt rating to the regression (Column 3 in Table 4), the coefficient of the lagged portfolio investment remains significant. The coefficient of lagged rating shows a statistically significant positive coefficient implying that one classification increase in the sovereign rating corresponds to about 0.056 percent increase in portfolio investment as a share of GDP. 


\section{Table 4: Portfolio Investment and Sovereign Rating}

Dependent variable: Portfolio Investment (\% of GDP)

Estimation Method: Arellano-Bover/Blundell-Bond Dynamic Panel System GMM.

\begin{tabular}{|c|c|c|c|c|c|c|c|c|c|}
\hline & [1] & [2] & [3] & [4] & [5] & [6] & [7] & [8] & [9] \\
\hline Portfolio $_{i t-1}$ & $\begin{array}{c}0.403 * * \\
* \\
(0.037)\end{array}$ & $\begin{array}{c}0.395 * * \\
* \\
(0.037)\end{array}$ & $\begin{array}{c}0.335^{* * * *} \\
(0.036)\end{array}$ & $\begin{array}{c}0.342 * * * \\
(0.041)\end{array}$ & $\begin{array}{l}0.351 * * * \\
(0.040)\end{array}$ & $\begin{array}{l}0.302 * * * \\
(0.032)\end{array}$ & $\begin{array}{c}0.299 * * * \\
(0.035)\end{array}$ & $\begin{array}{c}0.294 * * * \\
(0.032)\end{array}$ & $\begin{array}{c}0.293 * * * \\
(0.033)\end{array}$ \\
\hline GDP Growth $_{i t}$ & & $\begin{array}{c}0.125^{* *} \\
* \\
(0.033)\end{array}$ & $\begin{array}{c}0.087 * * * \\
(0.042)\end{array}$ & $\begin{array}{c}0.051 \\
(0.037)\end{array}$ & $\begin{array}{c}0.042 \\
(0.042)\end{array}$ & $\begin{array}{l}-0.020 \\
(0.038)\end{array}$ & $\begin{array}{l}-0.027 \\
(0.059)\end{array}$ & $\begin{array}{l}-0.035 \\
(0.062)\end{array}$ & \\
\hline Rating $_{\text {it }}$ & & & $\begin{array}{c}0.056^{* * * *} \\
(0.024)\end{array}$ & $\begin{array}{c}0.059 * * \\
(0.027)\end{array}$ & $\begin{array}{c}0.059 * * \\
(0.026)\end{array}$ & $\begin{array}{l}0.070 * * * \\
(0.022)\end{array}$ & $\begin{array}{c}0.0 .07 * * \\
* \\
(0.023)\end{array}$ & $\begin{array}{c}0.080^{* * * *} \\
(0.029)\end{array}$ & $\begin{array}{c}0.088 * * * \\
(0.022)\end{array}$ \\
\hline Inflation $_{i t}$ & & & & $\begin{array}{l}0.005 \\
(0.02)\end{array}$ & $\begin{array}{c}0.007 \\
(0.012)\end{array}$ & $\begin{array}{c}0.007 \\
(0.012)\end{array}$ & $\begin{array}{c}0.006 \\
(0.010)\end{array}$ & $\begin{array}{c}0.020 \\
(0.015)\end{array}$ & \\
\hline Real Interest Rate $_{i t}$ & & & & & $\begin{array}{l}-0.015 \\
(0.016)\end{array}$ & $\begin{array}{l}-0.014 \\
(0.013)\end{array}$ & $\begin{array}{l}-0.014 \\
(0.013)\end{array}$ & $\begin{array}{l}-0.005 \\
(0.010)\end{array}$ & \\
\hline Current Account ${ }_{i t}$ & & & & & & $\begin{array}{c}-0.087 * * \\
(0.036)\end{array}$ & $\begin{array}{c}-0.088 * * \\
(0.037)\end{array}$ & $\begin{array}{c}-0.093 * * \\
(0.040)\end{array}$ & $\begin{array}{l}-0.598^{*} \\
(0.032)\end{array}$ \\
\hline G-7 Growth $i t$ & & & & & & & $\begin{array}{c}0.031 \\
(0.138)\end{array}$ & $\begin{array}{c}0.120 \\
(0.187)\end{array}$ & \\
\hline G-7 Real Interest ${ }_{i t}$ & & & & & & & & $\begin{array}{l}-0.092 \\
(0.077)\end{array}$ & \\
\hline $\begin{array}{l}\text { Countries/Observatio } \\
\mathrm{ns}\end{array}$ & $17 / 336$ & $17 / 330$ & $17 / 315$ & $17 / 297$ & $16 / 271$ & $16 / 271$ & $16 / 271$ & $16 / 271$ & $23 / 435$ \\
\hline Arellano-Bond Test & & & & & & & & & \\
\hline Order 1 & $\begin{array}{c}-1.897 * \\
{[0.058]}\end{array}$ & $\begin{array}{c}-1.843 * \\
{[0.065]}\end{array}$ & $\begin{array}{c}-1.891 * \\
{[0.058]}\end{array}$ & $\begin{array}{c}-1.759 * \\
{[0.078]}\end{array}$ & $\begin{array}{c}-1.746^{*} \\
{[0.081]}\end{array}$ & $\begin{array}{c}-1.805^{*} \\
{[0.071]}\end{array}$ & $\begin{array}{c}-1.799 * \\
{[0.072]}\end{array}$ & $\begin{array}{c}-1.802 * * \\
{[0.071]}\end{array}$ & $\begin{array}{c}-1.933^{* *} \\
{[0.053]}\end{array}$ \\
\hline Order 2 & $\begin{array}{c}2.008 \\
{[0.045]}\end{array}$ & $\begin{array}{c}2.044 \\
{[0.041]}\end{array}$ & $\begin{array}{c}1.557 \\
{[0.120]} \\
\end{array}$ & $\begin{array}{c}1.567 \\
{[0.117]} \\
\end{array}$ & $\begin{array}{c}2.023 \\
{[0.043]}\end{array}$ & $\begin{array}{c}1.177 \\
{[0.239]}\end{array}$ & $\begin{array}{c}1.255 \\
{[0.209]}\end{array}$ & $\begin{array}{c}0.928 \\
{[0.353]}\end{array}$ & $\begin{array}{c}0.521 \\
{[0.601]}\end{array}$ \\
\hline $\begin{array}{l}\text { J-Statistic / Sargan P- } \\
\text { value }\end{array}$ & $\begin{array}{c}4.31 \\
{[0.97]}\end{array}$ & $\begin{array}{l}15.35 \\
{[0.34]}\end{array}$ & $\begin{array}{l}14.55 \\
{[0.41]}\end{array}$ & $\begin{array}{l}15.40 \\
{[0.42]}\end{array}$ & $\begin{array}{l}12.97 \\
{[0.67]}\end{array}$ & $\begin{array}{l}10.39 \\
{[0.92]}\end{array}$ & $\begin{array}{c}10.48 \\
{[0.92]}\end{array}$ & $\begin{array}{c}9.58 \\
{[0.94]}\end{array}$ & $\begin{array}{c}9.58 \\
{[0.94]}\end{array}$ \\
\hline
\end{tabular}

Notes: ***, ** and * denotes statistical significance at the 1\%, 5\% and $10 \%$ levels respectively

Numbers in round parentheses (.) are the robust standard errors, and numbers in square parentheses [.] are the Arellano-Bond Autocorrelation Test P-value 
Adding the lagged inflation to the regression (Column 4 in Table 4), the coefficients of the lagged portfolio investment and lagged rating do not change in terms of the signs and statistical significance. The coefficient lagged GDP growth, however, turned insignificant once the lagged inflation variable was added to the regression. Also, the lagged inflation rate shows an unexpectedly statistical insignificant impact on portfolio investment and similar results were obtained when adding the lagged interest rate (Column 5 in Table 4). Next, adding the lagged current account as a percent of GDP (Column 6 in Table 4) the results show a negative statistical significant impact on portfolio investment where a one percent increase in the current account leads to 0.87 percent decrease in portfolio investment.

In contrast to the results of FDI regressions, the push factors are not statistically significantly affecting portfolio investment. Both the weighted average of the G-7 real GDP growth rate to the regression (Column 7 in Table 4) and the G-7 real interest rate (Column 8) are not statistically significantly affecting portfolio investment in EMs.

The last specification (Column 9 in Table 4) is run with the only three insignificant coefficients lagged FDI, sovereign rating, and current account as percent of GDP. The results show statistically significant coefficients with expected signs.

Finally, the Arellano-Bond test for autocorrelation suggest a no second autocorrelation between residuals of all specifications and the Sargan test for overidentification suggest that the set of instruments used in all regressions are exogenous.

To further investigate the impact of rating on capital flows, Tables 5 investigates the contagion effect of the BRICS countries on the inflow of FDI to the different countries of our sample excluding the BRICS countries. The variable BRICS Ratingit-1 is computed as the average of the rating of Brazil, Russia, India, China, and South Africa. As the results of Table 5 suggest, under all specification of the model, it can be noticed that the changes in the average rating of the BRICS countries exerts a positive significant impact on the other group of EMs in the sample.

Similarly, Table 6 shows the impact of the variability in sovereign debt rating of BRICS as a region on the inflow of portfolio investment flows to other EMs included in our sample, excluding BRICS. The results suggest that BRICS has a positive statistically significant contagion effect on the other EMs in the sample. The coefficient of the variable BRICS Ratingit-1 is statistically significant and positive in all specifications. 


\section{Table 5: BRICS Contagion Effect: Foreign Direct Investment and Sovereign Rating}

Dependent variable: Foreign Direct Investment (\% of GDP)

Estimation Method: Arellano-Bover/Blundell-Bond Dynamic Panel System GMM.

\begin{tabular}{|c|c|c|c|c|c|c|c|c|c|}
\hline & {$[1]$} & {$[2]$} & {$[3]$} & [4] & [5] & {$[6]$} & {$[7]$} & {$[8]$} & [9] \\
\hline $\mathrm{FDI}_{i t-1}$ & $\begin{array}{c}0.707^{* *} \\
* \\
(0.032)\end{array}$ & $\begin{array}{c}0.695^{* * *} \\
(0.027)\end{array}$ & $\begin{array}{c}0.637 * * * \\
(0.018)\end{array}$ & $\begin{array}{c}0.632 * * * \\
(0.022)\end{array}$ & $\begin{array}{c}0.631 * * * \\
(0.027)\end{array}$ & $\begin{array}{c}0.631 * * * \\
(0.030)\end{array}$ & $\begin{array}{c}0.646 * * * \\
(0.041)\end{array}$ & $\begin{array}{c}0.651^{* * * *} \\
(0.043)\end{array}$ & $\begin{array}{c}0.650 \text { *** } \\
(0.028)\end{array}$ \\
\hline GDP Growth $_{i t-I}$ & & $\begin{array}{c}0.499 * * * \\
(0.218)\end{array}$ & $\begin{array}{c}0.440 * * \\
(0.190)\end{array}$ & $\begin{array}{r}0.537 * * \\
(0.224)\end{array}$ & $\begin{array}{c}0.588^{* *} \\
(0.232)\end{array}$ & $\begin{array}{c}0.584 * * * \\
(0.218)\end{array}$ & $\begin{array}{l}0.315^{*} \\
(0.164)\end{array}$ & $\begin{array}{c}0.3111 * * \\
(0.165)\end{array}$ & $\begin{array}{r}0.249 * * \\
(0.149)\end{array}$ \\
\hline BRICS Rating it-1 & & & $\begin{array}{c}0.106 * * \\
(0.053)\end{array}$ & $\begin{array}{l}0.111^{*} \\
(0.060)\end{array}$ & $\begin{array}{l}0.102 * \\
(0.064)\end{array}$ & $\begin{array}{r}0.101 * * \\
(0.043)\end{array}$ & $\begin{array}{l}0.080^{*} \\
(0.044)\end{array}$ & $\begin{array}{l}0.083^{*} \\
(0.043)\end{array}$ & $\begin{array}{c}0.091 * * \\
(0.053)\end{array}$ \\
\hline Inflation it-1 & & & & $\begin{array}{l}0.0001 \\
(0.002)\end{array}$ & $\begin{array}{c}0.0004 \\
(0.0003)\end{array}$ & $\begin{array}{l}0.0004 \\
(0.0003)\end{array}$ & $\begin{array}{c}0.0001 \\
(0.0004)\end{array}$ & $\begin{array}{c}0.0002 \\
(0.0003)\end{array}$ & \\
\hline Real Interest Rate $_{i t-1}$ & & & & & $\begin{array}{c}0.0226^{*} \\
(0.016)\end{array}$ & $\begin{array}{c}0.026 \\
(0.021)\end{array}$ & $\begin{array}{l}-0.005 \\
(0.032)\end{array}$ & $\begin{array}{c}-0.0002 \\
(0.027)\end{array}$ & \\
\hline Current Account ${ }_{i t-1}$ & & & & & & $\begin{array}{l}0.005 \\
(0.083)\end{array}$ & $\begin{array}{c}0.027 \\
(0.075)\end{array}$ & $\begin{array}{c}0.024 \\
(0.076)\end{array}$ & \\
\hline G-7 Growth ${ }_{i t}$ & & & & & & & $\begin{array}{l}1.138^{* *} \\
(0.573)\end{array}$ & $\begin{array}{l}1.221 * \\
(0.665)\end{array}$ & $\begin{array}{l}1.030 * * \\
(0.509)\end{array}$ \\
\hline G-7 Real Interest ${ }_{i t}$ & & & & & & & & $\begin{array}{l}-0.058 \\
(0.072) \\
\end{array}$ & $\begin{array}{l}-0.046 \\
(0.074) \\
\end{array}$ \\
\hline $\begin{array}{l}\text { Countries/Observati } \\
\text { ons }\end{array}$ & $23 / 493$ & $23 / 487$ & $23 / 487$ & $23 / 446$ & $22 / 401$ & $22 / 400$ & $22 / 400$ & $22 / 400$ & $23 / 487$ \\
\hline Arellano-Bond Test & & & & & & & & & \\
\hline Order 1 & $2.042^{-} * *$ & $\begin{array}{c}-2.157 * * \\
{[0.031]}\end{array}$ & $\begin{array}{c}-2.319 * * \\
{[0.020]}\end{array}$ & $\begin{array}{c}-2.245^{* *} \\
{[0.025]}\end{array}$ & $\begin{array}{c}-2.246^{* *} \\
{[0.025]}\end{array}$ & $\begin{array}{c}-2.253^{* *} \\
{[0.024]}\end{array}$ & $\begin{array}{c}-2.264 * * \\
{[0.024]}\end{array}$ & $\begin{array}{c}-2.250 * * \\
{[0.025]}\end{array}$ & $\begin{array}{c}-2.324 * * \\
{[0.020]}\end{array}$ \\
\hline Order 2 & $\begin{array}{c}{[0.041]} \\
-1.265 \\
{[0.206]}\end{array}$ & $\begin{array}{l}-1.244 \\
{[0.214]}\end{array}$ & $\begin{array}{l}-1.223 \\
{[0.221]}\end{array}$ & $\begin{array}{l}-1.225 \\
{[0.220]}\end{array}$ & $\begin{array}{l}-1.210 \\
{[0.226]}\end{array}$ & $\begin{array}{l}-1.212 \\
{[0.225]}\end{array}$ & $\begin{array}{l}-1.226 \\
{[0.220]}\end{array}$ & $\begin{array}{l}-1.227 \\
{[0.220]}\end{array}$ & $\begin{array}{l}-1.225 \\
{[0.220]}\end{array}$ \\
\hline
\end{tabular}

Notes: $* * *, * *$ and $*$ denotes statistical significance at the $1 \%, 5 \%$ and $10 \%$ levels respectively

Numbers in round parentheses (.) are the robust standard errors, and numbers in square parentheses [.] are the Arellano-Bond Autocorrelation Test P-value. 


\section{Table 6: BRICS Portfolio Investment and Sovereign Rating}

Dependent variable: Portfolio Investment (\% of GDP)

Estimation Method: Arellano-Bover/Blundell-Bond Dynamic Panel System GMM.

\begin{tabular}{|c|c|c|c|c|c|c|c|c|c|}
\hline & [1] & [2] & [3] & [4] & [5] & [6] & [7] & [8] & [9] \\
\hline Portfolio $_{i t-1}$ & $\begin{array}{c}0.403 * * \\
* \\
(0.037)\end{array}$ & $\begin{array}{c}0.395 * * \\
* \\
(0.037)\end{array}$ & $\begin{array}{c}0.366^{* * * *} \\
(0.041)\end{array}$ & $\begin{array}{c}0.377 * * * \\
(0.042)\end{array}$ & $\begin{array}{c}0.370 * * * \\
(0.041)\end{array}$ & $\begin{array}{c}0.299 * * * \\
(0.029)\end{array}$ & $\begin{array}{l}0.294 * * * \\
(0.032)\end{array}$ & $\begin{array}{c}0.291 * * * \\
(0.032)\end{array}$ & $\begin{array}{c}0.327 * * * \\
(0.031)\end{array}$ \\
\hline GDP Growth $_{i t}$ & & $\begin{array}{c}0.125^{* *} \\
* \\
(0.033)\end{array}$ & $\begin{array}{l}0.103 * * * \\
(0.033)\end{array}$ & $\begin{array}{c}0.078 * * \\
(0.035)\end{array}$ & $\begin{array}{c}0.092 * * \\
(0.047)\end{array}$ & $\begin{array}{l}-0.027 \\
(0.037)\end{array}$ & $\begin{array}{l}-0.020 \\
(0.058)\end{array}$ & $\begin{array}{l}-0.019 \\
(0.057)\end{array}$ & \\
\hline BRICS Rating $_{i t}$ & & & $\begin{array}{l}0.034 * * * \\
(0.012)\end{array}$ & $\begin{array}{c}0.035 * * \\
(0.016)\end{array}$ & $\begin{array}{l}0.028 * \\
(0.015)\end{array}$ & $\begin{array}{l}0.061 * * * \\
(0.018)\end{array}$ & $\begin{array}{c}0.062 * * * \\
(0.019)\end{array}$ & $\begin{array}{l}0.062 * * * \\
(0.020)\end{array}$ & $\begin{array}{c}0.053 * * * \\
(0.019)\end{array}$ \\
\hline Inflation $_{i t}$ & & & & $\begin{array}{c}0.0002 \\
(0.0003)\end{array}$ & $\begin{array}{c}0.019 \\
(0.015)\end{array}$ & $\begin{array}{c}0.017 \\
(0.014)\end{array}$ & $\begin{array}{c}0.015 \\
(0.010)\end{array}$ & $\begin{array}{c}0.018 \\
(0.016)\end{array}$ & \\
\hline Real Interest Rate $_{i t}$ & & & & & $\begin{array}{l}-0.008 \\
(0.014)\end{array}$ & $\begin{array}{c}-0.011 \\
(0.013)\end{array}$ & $\begin{array}{l}-0.011 \\
(0.014)\end{array}$ & $\begin{array}{l}-0.008 \\
(0.011)\end{array}$ & \\
\hline Current Account $_{i t}$ & & & & & & $\begin{array}{c}- \\
0.112 * * * \\
(0.039)\end{array}$ & $\begin{array}{c}- \\
0.113 * * * \\
(0.042)\end{array}$ & $\begin{array}{c}- \\
0.116^{* * * *} \\
(0.044)\end{array}$ & $\begin{array}{c}-0.080 * * \\
(0.036)\end{array}$ \\
\hline G-7 Growth $i t$ & & & & & & & $\begin{array}{c}0.068 \\
(0.143)\end{array}$ & $\begin{array}{c}0.094 \\
(0.173)\end{array}$ & \\
\hline G-7 Real Interest ${ }_{i t}$ & & & & & & & & $\begin{array}{l}-0.026 \\
(0.055) \\
\end{array}$ & \\
\hline $\begin{array}{l}\text { Countries/Observatio } \\
\text { ns }\end{array}$ & $17 / 336$ & $17 / 330$ & $17 / 330$ & $17 / 312$ & $16 / 279$ & $16 / 279$ & $16 / 279$ & $16 / 279$ & $17 / 336$ \\
\hline Arellano-Bond Test & & & & & & & & & \\
\hline Order 1 & $\begin{array}{l}-1.897 * \\
{[0.058]}\end{array}$ & $\begin{array}{l}-1.843^{*} \\
{[0.065]}\end{array}$ & $\begin{array}{l}-1.828 * \\
{[0.067]}\end{array}$ & $\begin{array}{l}-1.719 * \\
{[0.088]}\end{array}$ & $\begin{array}{l}-1.711 * \\
{[0.087]}\end{array}$ & $\begin{array}{l}-1.786^{*} \\
{[0.074]}\end{array}$ & $\begin{array}{l}-1.780 * \\
{[0.075]}\end{array}$ & $\begin{array}{l}-1.770 * \\
{[0.075]}\end{array}$ & $\begin{array}{l}-1.914 * \\
{[0.055]}\end{array}$ \\
\hline Order 2 & $\begin{array}{c}2.008 \\
{[0.045]}\end{array}$ & $\begin{array}{c}2.044 \\
{[0.041]}\end{array}$ & $\begin{array}{c}1.971 \\
{[0.048]}\end{array}$ & $\begin{array}{c}1.851 \\
{[0.064]}\end{array}$ & $\begin{array}{c}2.20 \\
{[0.028]}\end{array}$ & $\begin{array}{c}1.213 \\
{[0.225]}\end{array}$ & $\begin{array}{c}1.284 \\
{[0.199]}\end{array}$ & $\begin{array}{c}1.206 \\
{[0.228]}\end{array}$ & $\begin{array}{c}0.935 \\
{[0.350]}\end{array}$ \\
\hline
\end{tabular}

Numbers in round parentheses (.) are the robust standard errors, and numbers in square parentheses [.] are the Arellano-Bond Autocorrelation Test P-value. 
To add more depth to the analysis, we investigate this contagion effect per BRICS countries on the other countries included in the sample. In Table 7, five different regressions are performed where the impact of the sovereign debt rating of each of the five BRICS countries is included in a turn in the model in order to estimate its effect on the FDI of the group of EMs in our sample. For instance the first column shows the effect of the changes in Brazil's sovereign debt rating on FDI of all the countries included in our sample with the exception of Brazil. As the results suggest, the changes in Brazil's rating exerts a statistical significant impact on the FDI of EMs (with the exception of Brazil).

Table 7: BRICS Contagion Effect per Countries: Foreign Direct Investment and Sovereign Rating

Dependent variable: Foreign Direct Investment (\% of GDP)

Estimation Method: Arellano-Bover/Blundell-Bond Dynamic Panel System GMM.

\begin{tabular}{|c|c|c|c|c|c|}
\hline & $\begin{array}{c}\text { Brazil } \\
\text { (1) }\end{array}$ & $\begin{array}{c}\text { Russia } \\
\text { (2) }\end{array}$ & $\begin{array}{c}\text { India } \\
\text { (3) } \\
\end{array}$ & $\begin{array}{c}\text { China } \\
(4) \\
\end{array}$ & $\begin{array}{c}\text { South } \\
\text { Africa } \\
(5)\end{array}$ \\
\hline FDI $_{i t-1}$ & $\begin{array}{c}0.656 * * \\
* \\
(0.027)\end{array}$ & $\begin{array}{c}0.648 * * * \\
(0.040)\end{array}$ & $\begin{array}{c}0.659 * * * \\
(0.044)\end{array}$ & $\begin{array}{c}0.649 * * * \\
(0.047)\end{array}$ & $\begin{array}{c}0.652 * * * \\
(0.041)\end{array}$ \\
\hline GDP Growth $_{i t}$ & $\begin{array}{l}0.323 * \\
(0.182)\end{array}$ & $\begin{array}{l}0.322 * \\
(0.184)\end{array}$ & $\begin{array}{l}0.296 * \\
(0.161)\end{array}$ & $\begin{array}{c}0.306 * * \\
(0.161)\end{array}$ & $\begin{array}{l}0.305 * \\
(0.178)\end{array}$ \\
\hline Country Rating ${ }_{i t-1}$ & $\begin{array}{l}0.099 * \\
(0.055)\end{array}$ & $\begin{array}{c}0.098 * * * \\
(0.031)\end{array}$ & $\begin{array}{c}0.095 \\
(0.062)\end{array}$ & $\begin{array}{l}0.082 * \\
(0.045)\end{array}$ & $\begin{array}{c}0.094 * * * \\
(0.032)\end{array}$ \\
\hline Inflation $_{i t-1}$ & $\begin{array}{l}-0.017 \\
(0.011)\end{array}$ & $\begin{array}{l}-0.015 \\
(0.012)\end{array}$ & $\begin{array}{c}0.0001 \\
(0.0004)\end{array}$ & $\begin{array}{l}-0.012 \\
(0.009)\end{array}$ & $\begin{array}{l}-0.012 \\
(0.010)\end{array}$ \\
\hline Real Interest Rate ${ }_{i t-1}$ & $\begin{array}{c}-0.004 \\
(0.363)\end{array}$ & $\begin{array}{l}-0.005 \\
(0.042)\end{array}$ & $\begin{array}{l}-0.002 \\
(0.027)\end{array}$ & $\begin{array}{c}0.001 \\
(0.029)\end{array}$ & $\begin{array}{c}-0.007 \\
(0.037)\end{array}$ \\
\hline Current Account ${ }_{i t-1}$ & $\begin{array}{c}0.023 \\
(0.089)\end{array}$ & $\begin{array}{c}0.021 \\
(0.101)\end{array}$ & $\begin{array}{c}0.036 \\
(0.077)\end{array}$ & $\begin{array}{c}0.029 \\
(0.079)\end{array}$ & $\begin{array}{c}0.021 \\
(0.085)\end{array}$ \\
\hline G-7 Growth ${ }_{i t}$ & $\begin{array}{c}1.29 * \\
(0.667)\end{array}$ & $\begin{array}{c}1.30 * \\
(0.668)\end{array}$ & $\begin{array}{l}1.127 * \\
(0.657)\end{array}$ & $\begin{array}{l}1.228 * \\
(0.650)\end{array}$ & $\begin{array}{l}1.287 * \\
(0.696)\end{array}$ \\
\hline G-7 Real Interest ${ }_{i t}$ & $\begin{array}{l}-0.038 \\
(0.065)\end{array}$ & $\begin{array}{c}0.024 \\
(0.085)\end{array}$ & $\begin{array}{l}-0.124 \\
(0.061)\end{array}$ & $\begin{array}{l}-0.089 \\
(0.061)\end{array}$ & $\begin{array}{l}-0.0756 \\
(0.082)\end{array}$ \\
\hline $\begin{array}{l}\text { Countries/Observatio } \\
\mathrm{ns}\end{array}$ & $22 / 345$ & $22 / 329$ & $22 / 400$ & $22 / 374$ & $22 / 360$ \\
\hline Arellano-Bond Test & & & & & \\
\hline Order 1 & $2.193 * *$ & $\begin{array}{c}-2.162 * * \\
{[0.031]}\end{array}$ & $\begin{array}{c}-2.228 * * \\
{[0.026]}\end{array}$ & $\begin{array}{c}-2.239 * * \\
{[0.025]}\end{array}$ & $\begin{array}{c}-2.222 * * \\
{[0.026]}\end{array}$ \\
\hline Order 2 & $\begin{array}{c}{[0.028]} \\
-1.218 \\
{[0.223]}\end{array}$ & $\begin{array}{l}-1.225 \\
{[0.220]}\end{array}$ & $\begin{array}{c}-1.233 \\
{[0.217]}\end{array}$ & $\begin{array}{l}-1.217 \\
{[0.223]}\end{array}$ & $\begin{array}{c}-1.214 \\
{[0.224]}\end{array}$ \\
\hline
\end{tabular}

Notes: ***, ** and * denotes statistical significance at the 1\%, 5\% and $10 \%$ levels respectively

Numbers in round parentheses (.) are the robust standard errors, and numbers in square parentheses [.] are the Arellano-Bond Autocorrelation Test P-value.

It is important to note that given that the objective of this part of the study is to analyze the contagion effect of each of the BRICS countries on the rest of the countries in the sample, the sub $\mathrm{i}$ index attached to all the regressors of Table 7 refers to all countries in the sample with the exception of the country for which the regression is run. For instance in Column 2 of Table 7, the rating of Russia is included in the model but Russia itself is excluded from the sample. The same goes for the other four regressions. The results of Column 2 show that 
variability in ratings in Russia has a positive statistically significant impact of FDI of the other countries in the sample.

The table also shows that the changes in sovereign debt rating in either China or South Africa leads to a positive statistically significant impact on FDI for the group of EMs in our sample. The results of Column 3 of Table 7 shows that variability in India's rating does not exert a statistical significant impact on the EMs of our sample.

Similarly, Table 8 shows five regressions performed where in each regression one of the BRICS countries' rating is taken in a turn in order to estimate its impact on the portfolio investment of the group of EMs of our sample. As was the case in Table 7, given that we are measuring contagion effect, in each regression of Table 8 the sub I index under each regressor includes all the countries in the sample with the exception to the country for which the regression is run.

Table 8: BRICS Contagion Effect per Countries: Portfolio Investment and Sovereign Rating

Dependent variable: Portfolio Investment (\% of GDP)

Estimation Method: Arellano-Bover/Blundell-Bond Dynamic Panel System GMM.

\begin{tabular}{|c|c|c|c|c|c|}
\hline & $\begin{array}{c}\text { Brazil } \\
\text { (1) }\end{array}$ & $\begin{array}{c}\text { Russia } \\
\text { (2) }\end{array}$ & $\begin{array}{c}\text { India } \\
\text { (3) }\end{array}$ & $\begin{array}{c}\text { China } \\
\text { (4) }\end{array}$ & $\begin{array}{c}\text { South } \\
\text { Africa } \\
\text { (5) }\end{array}$ \\
\hline Portfolio $_{i t-1}$ & $\begin{array}{c}0.299 * * * \\
(0.031)\end{array}$ & $\begin{array}{c}0.272 * * * \\
(0.031)\end{array}$ & $\begin{array}{c}0.292 * * * \\
(0.032)\end{array}$ & $\begin{array}{c}0.286^{* * * *} \\
(0.030)\end{array}$ & $\begin{array}{c}0.284 * * * \\
(0.031)\end{array}$ \\
\hline GDP Growth $_{i t}$ & $\begin{array}{c}0.026 \\
(0.052)\end{array}$ & $\begin{array}{c}0.007 \\
(0.074)\end{array}$ & $\begin{array}{l}-0.055 \\
(0.063)\end{array}$ & $\begin{array}{l}-0.042 \\
(0.060)\end{array}$ & $\begin{array}{c}0.011 \\
(0.055)\end{array}$ \\
\hline Rating $_{i t}$ & $\begin{array}{l}0.070 * * * \\
(0.026)\end{array}$ & $\begin{array}{c}0.051 * * \\
(0.029)\end{array}$ & $\begin{array}{l}0.103 * * * \\
(0.035)\end{array}$ & $\begin{array}{c}0.070 * * * \\
(0.025)\end{array}$ & $\begin{array}{c}0.058 * * * \\
(0.022)\end{array}$ \\
\hline Inflation $i t$ & $\begin{array}{c}0.015 \\
(0.010)\end{array}$ & $\begin{array}{c}0.011 \\
(0.014)\end{array}$ & $\begin{array}{c}0.007 \\
(0.014)\end{array}$ & $\begin{array}{c}0.009 \\
(0.014)\end{array}$ & $\begin{array}{c}0.021 \\
(0.014)\end{array}$ \\
\hline Real Interest Rate $_{i t}$ & $\begin{array}{l}-0.002 \\
(0.011)\end{array}$ & $\begin{array}{l}-0.001 \\
(0.012)\end{array}$ & $\begin{array}{l}-0.009 \\
(0.011)\end{array}$ & $\begin{array}{l}-0.010 \\
(0.011)\end{array}$ & $\begin{array}{l}-0.006 \\
(0.011)\end{array}$ \\
\hline Current Account ${ }_{i t}$ & $\begin{array}{c}- \\
0.109 * * * \\
(0.033)\end{array}$ & $\begin{array}{c}- \\
0.104 * * * \\
(0.035)\end{array}$ & $\begin{array}{c}-0.111 * * \\
(0.046)\end{array}$ & $\begin{array}{c}-0.117 * * \\
(0.047)\end{array}$ & $\begin{array}{c}-0.120 * * * \\
(0.032)\end{array}$ \\
\hline G-7 Growth $i t$ & $\begin{array}{c}0.109 \\
(0.199)\end{array}$ & $\begin{array}{l}0.115 \\
(0.222)\end{array}$ & $\begin{array}{c}0.143 \\
(0.189)\end{array}$ & $\begin{array}{c}0.121 \\
(0.185)\end{array}$ & $\begin{array}{c}0.052 \\
(0.169)\end{array}$ \\
\hline G-7 Real Interest ${ }_{i t}$ & $\begin{array}{l}-0.038 \\
(0.068) \\
\end{array}$ & $\begin{array}{c}0.013 \\
(0.055) \\
\end{array}$ & $\begin{array}{l}-0.088 \\
(0.075)\end{array}$ & $\begin{array}{l}-0.061 \\
(0.069)\end{array}$ & $\begin{array}{c}-0.35 \\
(0.059)\end{array}$ \\
\hline $\begin{array}{l}\text { Countries/Observatio } \\
\text { ns }\end{array}$ & $16 / 251$ & $16 / 240$ & $16 / 279$ & $16 / 270$ & $16 / 261$ \\
\hline Arellano-Bond Test & & & & & \\
\hline Order 1 & $\begin{array}{c}-1.806^{*} \\
{[0.071]}\end{array}$ & $\begin{array}{c}-1.844 * \\
{[0.065]}\end{array}$ & $\begin{array}{l}-1.767 * \\
{[0.072]}\end{array}$ & $\begin{array}{r}-1.783^{*} \\
{[0.075]}\end{array}$ & $\begin{array}{l}-1.848^{*} \\
{[0.064]}\end{array}$ \\
\hline Order 2 & $\begin{array}{l}0.041 * \\
{[0.968]}\end{array}$ & $\begin{array}{l}-0.252 * \\
{[0.252]}\end{array}$ & $\begin{array}{c}1.292 \\
{[0.197]}\end{array}$ & $\begin{array}{c}1.144 \\
{[0.252]}\end{array}$ & $\begin{array}{c}0.770 \\
[0.441]]\end{array}$ \\
\hline $\begin{array}{l}\text { J-Statistic / Sargan P- } \\
\text { value }\end{array}$ & $\begin{array}{l}12.97 \\
{[0.67]}\end{array}$ & $\begin{array}{c}10.39 \\
{[0.92]}\end{array}$ & $\begin{array}{c}10.48 \\
{[0.92]}\end{array}$ & $\begin{array}{c}9.58 \\
{[0.94]}\end{array}$ & $\begin{array}{c}9.58 \\
{[0.94]}\end{array}$ \\
\hline
\end{tabular}

Notes: $* * *, * *$ and $*$ denotes statistical significance at the 1\%, 5\% and $10 \%$ levels respectively Numbers in round parentheses (.) are the robust standard errors, and numbers in square parentheses [.] are the ArellanoBond Autocorrelation Test P-value. 
As the results of Table 8 suggest, the changes in the sovereign debt rating of Brazil has a positive statistical significant impact on the portfolio investment as a percentage of GDP of the group of other EMs included in the sample. The same result applies for Russia, India, China, and South Africa where variability of rating in each one of these countries exerts a statistically significant contagion effect on other EMs included in the sample.

Furthermore, it is interesting to investigate the impact of rating on capital flows in the presence of the 2007-2009 global financial crisis. To measure this effect, a dummy variable for the crisis is added to the model to imply the presence of the crisis along with an interaction term of this dummy with the rating regressor. The total effect of the presence of the crisis is measured as the sum of the coefficient of the dummy variable and the coefficient of the interaction term. The standard error of this linear combination is calculated and used to compute the t-statistic of the total effect.

Table 9: Global Financial Crisis Effect: Foreign Direct Investment and Sovereign Rating

Dependent variable: Foreign Direct Investment (\% of GDP)

Estimation Method: Arellano-Bover/Blundell-Bond Dynamic Panel System GMM.

\begin{tabular}{|c|c|c|}
\hline & [1] & [2] \\
\hline $\mathrm{FDI}_{i t-1}$ & $\begin{array}{c}0.628 * * \\
* \\
(0.058)\end{array}$ & $\begin{array}{c}0.620 * * * \\
(0.066)\end{array}$ \\
\hline GDP Growth $_{i t-1}$ & $\begin{array}{l}0.290^{*} \\
(0.178)\end{array}$ & $\begin{array}{c}0.308 * * \\
(0.195)\end{array}$ \\
\hline Rating it-1 & $\begin{array}{c}0.198 * * \\
* \\
(0.046)\end{array}$ & $\begin{array}{c}0.196 * * * \\
(0.047)\end{array}$ \\
\hline Inflation it-1 & $\begin{array}{c}0.003 \\
(0.008)\end{array}$ & $\begin{array}{c}0.001 \\
(0.009)\end{array}$ \\
\hline Real Interest Rate $_{i t-1}$ & $\begin{array}{r}-0.0004 \\
(0.034)\end{array}$ & $\begin{array}{l}-0.0005 \\
(0.033)\end{array}$ \\
\hline Current Account $_{i t-1}$ & $\begin{array}{c}0.032 \\
(0.072)\end{array}$ & $\begin{array}{c}0.025 \\
(0.067)\end{array}$ \\
\hline G-7 Growth ${ }_{i t}$ & $\begin{array}{r}1.071 * * \\
(0.597)\end{array}$ & $\begin{array}{l}1.047 * * \\
(0.599)\end{array}$ \\
\hline G-7 Real Interest ${ }_{i t}$ & $\begin{array}{c}- \\
0.322 * * \\
(0.166)\end{array}$ & $\begin{array}{c}-0.310 * * \\
(0.170)\end{array}$ \\
\hline Crisis Dummy $_{t-1}$ & $\begin{array}{l}-0.924 \\
(0.893)\end{array}$ & $\begin{array}{c}-2.817 * * \\
(1.520)\end{array}$ \\
\hline Crisis Rating Interaction $_{i t-1}$ & & $\begin{array}{r}0.148 \\
(0.157) \\
\end{array}$ \\
\hline $\begin{array}{l}\text { Total Effect of Rating } \\
\text { And Crisis }\end{array}$ & & $\begin{array}{c}0.345^{* * * *} \\
(0.119) \\
\end{array}$ \\
\hline Countries/Observations & $22 / 366$ & $22 / 366$ \\
\hline $\begin{array}{l}\text { Arellano-Bond Test } \\
\text { Order } 1\end{array}$ & $2.203 * *$ & $\begin{array}{c}-2.250 * * \\
{[0.024]}\end{array}$ \\
\hline Order 2 & $\begin{array}{c}{[0.024]} \\
-1.219 \\
{[0.228]}\end{array}$ & $\begin{array}{l}-1.225 \\
{[0.221]}\end{array}$ \\
\hline
\end{tabular}

Notes: $* * *, * *$ and $*$ denotes statistical significance at the $1 \%, 5 \%$ and $10 \%$ levels respectively Numbers in round parentheses (.) are the robust standard errors, and numbers in square parentheses [.] are the Arellano-Bond Autocorrelation Test P-value. 
The results of Tables 9 suggest that the dummy variable representing the crisis is statistically significant. Also, and more importantly, the total effect of rating in the presence of the crisis suggests that the effect of rating on FDI increases during the times of a crisis than times without. The total effect shows a positive and a statistically significant coefficient

Similarly, the impact of sovereign debt rating on portfolio investment in the presence of the financial crisis dummy is estimated in Table 10. The results of Column 1 of Table 10 show that the crisis dummy is statistically insignificant. Also, adding the interaction term to the regression as shown in Column 2 of the same table shows that the total effect of rating in the presence of the crisis has no statistical significant impact on portfolio investment.

Table 10: Global Financial Crisis Effect: Portfolio Investment and Sovereign Rating

Dependent variable: Portfolio Investment (\% of GDP)

Estimation Method: Arellano-Bover/Blundell-Bond Dynamic Panel System GMM.

\begin{tabular}{|c|c|c|}
\hline & [1] & {$[2]$} \\
\hline Portfolio $_{i t-1}$ & $\begin{array}{l}0.294 * * * \\
(0.031)\end{array}$ & $\begin{array}{c}0.295 * * \\
* \\
(0.029)\end{array}$ \\
\hline GDP Growth $_{i t}$ & $\begin{array}{l}-0.032 \\
(0.058)\end{array}$ & $\begin{array}{l}-0.040 \\
(0.067)\end{array}$ \\
\hline Rating $_{i t}$ & $\begin{array}{l}0.090 * \\
(0.047)\end{array}$ & $\begin{array}{c}0.093 * * \\
(0.051)\end{array}$ \\
\hline Inflation $_{i t}$ & $\begin{array}{c}0.021 \\
(0.017)\end{array}$ & $\begin{array}{c}0.022 \\
(0.015)\end{array}$ \\
\hline Real Interest Rate $_{i t}$ & $\begin{array}{l}-0.005 \\
(0.010)\end{array}$ & $\begin{array}{l}-0.005 \\
(0.010)\end{array}$ \\
\hline Current Account ${ }_{i t}$ & $\begin{array}{c}-0.090 * * \\
(0.037)\end{array}$ & $\begin{array}{c}- \\
0.093 * * \\
(0.040)\end{array}$ \\
\hline G-7 Growth $i t$ & $\begin{array}{c}0.095 \\
(0.152)\end{array}$ & $\begin{array}{c}0.120 \\
(0.187)\end{array}$ \\
\hline G-7 Real Interest ${ }_{i t}$ & $\begin{array}{l}-0.110 \\
(0.101)\end{array}$ & $\begin{array}{l}-0.092 \\
(0.077)\end{array}$ \\
\hline Crisis Dummy $_{t}$ & $\begin{array}{l}-0.141 \\
(0.313)\end{array}$ & $\begin{array}{c}0.120 \\
(0.187)\end{array}$ \\
\hline Crisis Rating Interaction $_{i t}$ & & $\begin{array}{l}-0.092 \\
(0.077)\end{array}$ \\
\hline $\begin{array}{l}\text { Total Effect of Rating } \\
\text { And Crisis }\end{array}$ & & $\begin{array}{l}0.0628 \\
(.074)\end{array}$ \\
\hline Countries/Observations & $16 / 271$ & $17 / 315$ \\
\hline $\begin{array}{l}\text { Arellano-Bond Test } \\
\text { Order } 1\end{array}$ & $\begin{array}{l}-1.799 * \\
{[0.072]}\end{array}$ & ${ }^{-}-$ \\
\hline Order 2 & $\begin{array}{c}1.255 \\
{[0.209]}\end{array}$ & $\begin{array}{c}{[0.071]} \\
0.928 \\
{[0.353]}\end{array}$ \\
\hline
\end{tabular}

Notes: $* * *, * *$ and $*$ denotes statistical significance at the 1\%, 5\% and $10 \%$

levels respectively. Numbers in round parentheses (.) are the robust standard errors,

and numbers in square parentheses [.] Jare the Arellano-Bond Autocorrelation Test P-value.

To sum up, estimating the impact of rating on portfolio investment in the presence of a crisis, our results suggest that neither the dummy nor the interaction term is significant. The combined effect, represented by the total effect, is also statistically insignificant. This result is an unexpected one and would consider further analysis. 


\section{Conclusion}

The study analyzes how the changes in sovereign rating influence different types of capital flows to EMs and whether the changes in the different kinds of capital flows in one country be explained by a sovereign ratings' change in another country. The results of the study suggest that sovereign rating is a crucial factor for EMs' access to international capital markets. Sovereign rating has a statistically significant effect on either FDI (as a percent of GDP) or portfolio investment (as a percent of GDP). Additionally, the results suggest that capital flows are a major source of financing for EMs, however, financial contagion may continue to be a threat to capital flowing into EMs. The BRICS as either a group or individual countries exert a statistically significant contagion effect on EMs. Finally, the presence of a financial crisis increases the impact of sovereign rating on FDI but not the case with portfolio flows.

\section{References}

Arellano, M. and S. Bond (1991);"'Some Tests of Specification for Panel Data: Monte Carlo Evidence and an Application to Employment Equations",Review of Economic Studies, 58, 277-297. doi: $10.2307 / 2297968$.

Albuquerque, Rui,(2003), "The Composition of International Capital Flows: Risk Sharing through Foreign Direct Investment." Journal of International Economics 61 (2): pp. 353-83. doi:10.1016/S0022-1996(03)00013-8

Caselli, Francesco \& Esquivel, Gerardo \& Lefort, Fernando, 1996. " Reopening the Convergence Debate: A New Look at Cross-Country Growth Empirics," Journal of Economic Growth, Springer, vol. 1(3), pages 363-89, September. doi:10.1007/BF00141044

Chuhan, P., S. Claessens, and N. Mamingi. 1993. Equity and Bond Flows to Asia and Latin America. The World Bank, Policy Research Working Papers, No.1160.

Eichengreen, Barry, Andrew K. Rose, and Charles Wyplosz (1995) "Exchange Market Mayhem: The Antecedents and Aftermath of Speculative Attacks," Economic Policy 21, pp.249-312. doi:10.2307/1344591.

Fernandez-Arias, E. and P. Montiel. (1995), The Surge in Capital Inflows to Developing Countries: An Analytical Overview. The World Bank Economic Review, 10, No.1.

Holtz-Eakin, D., W. Newey and H. Rosen (1988), "Estimating Vector Autoregressions with Panel Data", Econometrica, 56, 1371-1395. doi:10.2307/1913103.

Glick, Reuven \& Rose, Andrew K, (1998), "Contagion and Trade: Why are Currency Crises Regional," CEPR Discussion Papers No.1947, C.E.P.R. Discussion Papers.

Hernandez, L., P. Mellado, and R. Valdes. (2001), Determinants of Private Capital Flows in the 1970s and 1990s: Is There Evidence of Contagion? IMF Working Paper, No. 01/64.

Kaminsky and Schmukler (2002), Short-run pain, long-run gain: The effects of financial liberalization. World Bank Policy Research Working Paper 2912. doi:10.1596/1813-9450-2912

Juttner, J. D., and J. McCarthy (1998), Modeling a Ratings Crisis (unpublished, Sydney, Australia: Macquarie University), www.econ.mq.edu.au/courses/econ360/Soveig1.pdf

Taylor, M.P., Sarno, L., (1997), Capital flows to developing countries: long- and short-term determinants. The World Bank Economic Review, 11(3):pp. 451-470 